\title{
Faktor-Faktor Penyebab Cyberbullying yang Dilakukan Oleh Remaja di Kota Yogyakarta
}

\author{
Febrizal Antama*, Mukhtar Zuhdy \\ Fakultas Hukum, Universitas Muhammadiyah Yogyakarta \\ *Korespondensi : febrizal.antama.2016@law.umy.ac.id
}

\author{
Info Artikel \\ Riwayat: \\ Diajukan : 15 April 2021 \\ Ditelaah : 27 April 2021 \\ Direvisi : 31 Mei 2021 \\ Diterima : 02 Juli 2021 \\ Kata Kunci : \\ cyberbullying; kebijakan \\ kriminal; remaja \\ DOI: \\ 10.18196/ijclc .v2i2.12317
}

\begin{abstract}
Abstrak
Hadirnya ragam aplikasi internet berupa media sosial, game online, dan media komunikasi digital lainnya, dewasa ini telah menjadi wadah bagi terjadinya cyberbullying yang dilakukan oleh remaja di Kota Yogyakarta. Kasus cyberbullying yang dilakukan oleh remaja terus meningkat setiap tahunnya. Maka penting kiranya untuk mengetahui faktor-faktor penyebab terjadinya cyberbullying di Kota Yogyakarta. Sehingga dengan mengetahui faktor-faktor yang menyebabkan remaja melakukan cyberbullying, diharapkan kita dapat mengetahui kebijakan kriminal (criminal policy) baik melalui sarana penal maupun sarana non-penal yang tepat guna memberantas cyberbullying secara lebih efektif. Penelitian ini menggunakan jenis penelitian yuridis empiris. Sementara itu, sumber yang digunakan adalah bahan primer dan sekunder. Teknik yang digunakan adalah studi lapangan. Analisis data yang digunakan adalah analisis yang bersifat deskriptif kualitatif. Hasil dari penelitian ini menunjukan bahwa faktor yang menyebabkan remaja melakukan cyberbullying di Kota Yogyakarta antara lain: pesatnya perkembangan teknologi, ketidaktahuan remaja akan risiko hukum, perilaku remaja yang suka meniru, serta telah melemahnya kontrol sosial.
\end{abstract}

\section{Pendahuluan}

Hukum selalu berkembang seiring dengan berkembangnya masyarakat dan digunakan sebagai sarana pembaharuan. Hal tersebut terjadi karena law as a tool of social engineering (hukum merupakan alat rekayasa sosial) sehingga laju modernisasi yang cepat membuat hukum pun harus mengikuti perkembangan yang ada. Hal ini dilakukan semata-mata dalam rangka melindungi kepentingan masyarakat. Perkembangan teknologi yang semakin pesat menjadi salah satu faktor yang membawa banyak pengaruh bagi kehidupan masyarakat. Hadirnya teknologi membawa konsekuensi yang tidak dapat lagi dihindari dalam kehidupan sehari-hari karena setiap masyarakat pasti akan selalu bersentuhan dengan kecanggihan teknologi, sehingga hukum sebagai alat rekayasa sosial sangat penting untuk di gunakan dalam melindungi masyarakat.

Modernisasi akan selalu bergerak cepat guna memenuhi kebutuhan masyarakat yang semakin meningkat. Teknologi terus-menerus berkembang, hingga hadirlah jaringan internet yang membawa banyak manfaat. Jaringan internet sangat mempengaruhi kehidupan di seluruh dunia, tak terkecuali di Indonesia. Menurut survei yang dilakukan oleh Asosiasi Penyelenggara Jasa Internet Indonesia (APJII), pengguna aktif internet di Indonesia sebanyak 143,26 juta jiwa dari total 262 juta jiwa penduduk Indonesia. Artinya sebesar 64\% orang Indonesia sudah menggunakan internet. Dari jumlah pengguna internet tersebut, sebesar 80\% adalah remaja berusia 13-18 tahun. ${ }^{1}$ Angka tersebut terbilang sangat tinggi, sebab Indonesia adalah negara dengan pengguna internet terbanyak ke-9 dari 214 negara di

\footnotetext{
${ }^{1}$ Asosiasi Penyelenggara Jasa Internet Indonesia (APJII). (2009). Laporan Survei Penetrasi \& Profil Prilaku Pengguna Internet Indonesia.. Jakarta: 10 April 2019. h. 7
} 
dunia. ${ }^{2}$ Satu diantara banyaknya aplikasi dalam jaringan internet yang paling sering diakses adalah media sosial. Menurut Asosiasi Penyelenggara Jasa Internet Indonesia (APJII), ada 91\% pengguna internet yang mengakses media sosial. ${ }^{3}$ Melalui media sosial setiap orang dapat berinteraksi dan berbagi informasi tanpa harus bertatap muka. Meskipun media sosial dan aplikasi dalam jaringan internet lainnya telah membantu banyak hal bagi penggunanya, akan tetapi ternyata media sosial juga memiliki sifat yang merusak.

Sejalan dengan masifnya penggunaan internet, telah muncul kejahatan baru yang kemudian disebut sebagai cyber crime atau kejahatan siber. Cyber crime atau kejahatan siber merupakan salah satu kejahatan baru yang menggunakan media elektronik atau internet dan terus mengalami perkembangan mulai dari modus maupun ragam kejahatannya. ${ }^{4}$ Salah satu jenis cyber crime adalah cyberbullying. Cyberbullying sejatinya serupa dengan bullying yang dilakukan secara tradisional, perbedaannya cyberbullying menggunakan sarana teknologi digital atau internet. ${ }^{5}$

Istilah cyberbullying merupakan sesuatu yang baru di tengah masyarakat, meskipun demikian cyberbullying mulai mengkhawatirkan. Menurut data dari Komisi Perlindungan Anak Indonesia, jumlah kasus cyberbullying terus meningkat dari tahun ketahun. Adapun rincian kasus cyberbullying yaitu, pada tahun 2016 terdapat 56 kasus, pada tahun 2017 mengalami peningkatan menjadi 73 kasus, dan di tahun 2018 jumlahnya melonjak menjadi 117 kasus. Yang memprihatinkan adalah mayoritas cyberbulling tersebut menjadikan anak-anak sebagai korban. Adapun rincian kasus cyberbullying dengan anak sebagai korban yaitu pada tahun 2016 terdapat 34 kasus, di tahun 2017 naik menjadi 55 kasus, dan di tahun 2018 meningkat secara signifikan menjadi 109 kasus. $^{6}$

Tulisan ini akan berfokus pada cyberbullying yang dilakukan oleh remaja di Kota Yogyakarta. Kota Yogyakarta dipilih karena beberapa pertimbangan. Pertama, Kota Yogyakarta menjadi daerah dengan pengguna internet terbanyak ke dua di Indonesia dengan persentase pengguna internet di Yogyakarta sebesar 73,8\% dari total jumlah penduduk. ${ }^{7}$ Kedua, banyaknya jumlah pelajar, tingginya angka kenakalan remaja, serta latar belakang sosial yang beraneka ragam, menjadikan Yogyakarta potensial untuk dijadikan tempat penelitian.

Cyberbullying telah menjadi realita yang terjadi di tengah masyarakat. Sehingga sangat penting untuk mengkaji lebih lanjut tentang faktor apa yang menyebabkan remaja di Kota Yogyakarta melakukan cyberbullying. Setelah faktor penyebab tersebut diketahui, akan mempermudah untuk menentukan kebijakan kriminal (criminal policy) yang dapat digunakan baik melalui sarana penal maupun sarana nonpenal agar penanggulangan terhadap cyberbullying dapat dilakukan lebih efektif. ${ }^{8}$ Berdasarkan latar belakang tersebut, tulisan ini akan membahas tentang faktor-faktor penyebab terjadi cyberbullying yang dilakukan oleh remaja di Yogyakarta.

\section{Metode Penelitian}

Penelitian yang dilakukan penulis menggunakan jenis penelitian yuridis empiris. Penelitian empiris penting untuk dilakukan, sebab ahli hukum dan pembuat kebijakan harus mampu memahami secara utuh kondisi dan situasi sosial kemasyarakatan di mana hukum itu diterapkan, sehingga

\footnotetext{
${ }^{2}$ Tim Penyusun Wikipedia. (2019). Daftar Negara Menurut Jumlah Pengguna Internet. Diakses pada

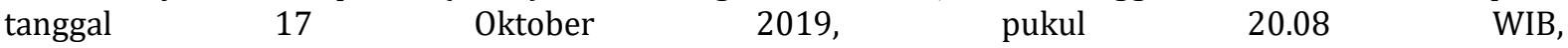
https://id.wikipedia.org/wiki/Daftar negara menurut jumlah pengguna Internet

${ }^{3}$ Asosiasi Penyelenggara Jasa Internet Indonesia (APJII), Op. Cit., h. 20.

${ }^{4}$ Maskun. (2014). Kejahatan Siber (Cyber Crime): Suatu Pengantar. Jakarta: Prenada Media Group. h. 4748.

${ }^{5}$ Donegan, R. (2012), Bullying and Cyberbullying: History, Statistics, Law, Prevention and Analysis, The Elon Journal of Undergraduate Research in Communications, 1(3). h. 34.

${ }^{6}$ Mardina. R. (2019). Kekerasan Terhadap Anak dan Remaja. Jakarta: Infodatin. h. 6-7

${ }^{7}$ Asosiasi Penyelenggara Jasa Internet Indonesia (APJII), Op.Cit., h.14.

${ }^{8}$ Ravena, D \& Kristian, (2017), Kebijakan Kriminal (Criminal Policy), Jakarta: Kencana, h. vi.
} 
diharapkan mampu menciptakan nilai guna ilmu hukum bagi masyarakat. ${ }^{9}$ Penelitian ini menggunakan data primer dan data sekunder. Lokasi Penelitian ini dilakukan di Kota Yogyakarta. Penelitian ini juga didukung wawancara bersama responden dan narasumber. Adapun teknik pengumpulan data yang digunakan dalam penelitian ini ialah studi kepustakaan dan studi lapangan melalui wawancara dan angket/kuisioner. Hasil dari penelitian yang terkumpul akan dianalisis dengan menggunakan metode deskriptif, yaitu peneliti dalam menganalisis berkeinginan untuk memberikan gambaran atau pemaparan atas subjek dan objek penelitian sebagaimana hasil penelitian yang telah dilakukan. Pendekatan yang dilakukan dalam penelitian ini adalah pendekatan kualitatif yaitu suatu cara analisis hasil penelitian berdasarkan mutu yang merupakan kumpulan data yang dilakukan baik secara tertulis maupun lisan serta tingkah laku yang nyata yang diteliti dan dipelajari sebagai sesuatu yang utuh. ${ }^{10}$

\section{Hasil dan Pembahasan}

\section{A. Gambaran Umum Cyberbullying yang Dilakukan oleh Remaja}

Merebaknya cyberbullying merupakan konsekuensi dari perkembangan teknologi yang semakin pesat. Cyberbullying telah merebak dan banyak dilakukan oleh remaja di Indonesia, tidak terkecuali di Kota Yogyakarta. Agar mendapatkan hasil penelitian yang komprehensif, penulis melakukan penelitian di berbagai tempat di Daerah Istimewa Yogyakarta. Setelah melakukan penelitian, penulis memperoleh data terkait kriminalitas cyberbullying dari berbagai institusi, seperti Polda DIY, Polresta Kota Yogyakarta, dan Yayasan Lembaga Perlindungan Anak DIY.

Alasan mengapa penulis melakukan penelitian di berbagai institusi adalah karena kasus cyberbullying yang dilakukan oleh remaja di Kota Yogyakarta ternyata tidak semua dilaporkan pada satu institusi saja, namun tersebar di berbagai institusi. Bahkan dalam satu institusi, kasus cyberbullying pun tersebar ke beberapa direktorat. Berikut adalah jumlah kasus cyberbullying berdasarkan masing-masing institusi. Agar lebih jelas, akan penulis paparkan dalam bentuk tabel sebagai berikut:

Tabel 1 Kasus Cyberbullying di Kota Yogyakarta.

\begin{tabular}{clcc}
\hline No & \multicolumn{1}{c}{ Instansi } & Frekuensi (Kasus) & Presentasi \\
\hline 1. & Polda DIY & 4 & $40 \%$ \\
2. & Polresta Kota Yogyakarta & 2 & $20 \%$ \\
3. & Yayasan Lembaga Perlindungan Anak & 4 & $40 \%$ \\
& DIY & 10 & $100 \%$ \\
\hline \multicolumn{4}{c}{ Jumlah } \\
Sumber: Data primer, diperoleh dari Polda DIY, Polresta Kota Yogyakarta, dan Yayasan
\end{tabular}

Berdasarkan data di atas, terlihat jelas bahwa kasus cyberbullying yang tercatat di berbagai institusi di Yogyakarta jumlahnya relatif sedikit. Kasus cyberbullying yang ditangani oleh Polda DIY sebanyak empat kasus, kemudian Polresta Kota Yogyakarta menangani dua kasus, serta Yayasan Lembaga Perlindungan Anak DIY menangani enam kasus remaja yang melakukan cyberbullying. Minimnya catatan kriminal pada institusi di Kota Yogyakarta terkait kasus cyberbullying tidak dapat menjadi parameter dan menjustifikasi bahwa cyberbullying di Kota Yogyakarta rendah. Sebab sebagaimana telah kita ketahui, bahwa tidak semua kejahatan tercatat oleh kepolisian. Kriminalitas yang tercatat oleh polisi sebatas pada tindak pidana yang diketahui oleh pihak polisi saja. Banyak tindak pidana yang terjadi tetapi tidak diketahui oleh kepolisian, inilah yang kemudian disebut dark number (angka gelap kejahatan).

Menurut Pranawa, selaku Koordinator Layanan Hukum Yayasan Lembaga Perlindungan Anak DIY, kasus bullying baik yang dilakukan melalui media sosial maupun yang dilakukan secara tradisional

\footnotetext{
${ }^{9}$ Fajar ND, M \& Achmad, Y. (2017). Dualisme Penulisan Hukum Normatif \& Empiris. Yogyakarta: Pustaka Pelajar. h.44-45

${ }^{10}$ Ibid, h. 183-192.
} 
sebenarnya sangat banyak di Kota Yogyakarta, akan tetapi hampir semuanya diselesaikan secara kekeluargaan dalam tataran sekolah. Sehingga dapat diketahui bahwa kejahatan yang tidak tercatat pihak kepolisan sejatinya jauh lebih banyak dari pada yang tercatat. Dalam konteks ini, banyaknya cyberbullying yang tidak tercatat oleh pihak kepolisian, sebagaimana yang dikatakan oleh Lidwina Esti Wulandari,11 yang disebabkan oleh beberapa faktor, antara lain:

1. Korban cyberbullying menganggap bahwa tidak begitu penting melaporkan kejadian itu pada polisi;

2. Kerumitan sistem pelaporan yang menghabiskan waktu dan bertele-tele;

3. Pelaku lihai menghilangkan jejak (pada kasus cyberbullying yang menggunakan akun yang tidak dikenali).

Membicarakan mengenai kenakalan remaja tentu penting untuk membahas rentang usia remaja yang melakukan kenakalan. Maka dari itu, penulis akan membagi remaja yang melakukan cyberbullying di Kota Yogyakarta berdasarkan tingkatan usianya. Adapun usia remaja yang melakukan cyberbullying, dan telah tercatat oleh institusi di Kota Yogyakarta sebagai berikut:

Tabel 2 Usia Pelaku Cyberbullying di Kota Yogyakarta

\begin{tabular}{cccc}
\hline No & Usia Pelaku & Frekuensi (Orang) & Presentasi \\
\hline 1. & 13 tahun & 1 & $10 \%$ \\
2. & 14 tahun & 2 & $20 \%$ \\
3. & 15 tahun & - & - \\
4. & 16 tahun & 5 & $50 \%$ \\
5. & 17 tahun & 2 & $20 \%$ \\
\hline & Jumlah & 10 & $100 \%$ \\
\hline
\end{tabular}

Sumber : Data Primer, diperoleh dari Polda DIY, Polresta Kota Yogyakarta, dan Yayasan Lembaga Perlindungan Anak DIY.

Usia remaja yang paling banyak melakukan cyberbullying sebagaimana data di atas adalah remaja berusia 16 tahun, terdapat lima pelaku atau sebesar 50\% dari yang tercatat melakukan cyberbullying. Selanjutnya sebanyak dua pelaku atau sebesar $20 \%$ adalah remaja berusia 14 tahun. Kemudian terdapat dua pelaku cyberbullying atau sebesar $20 \%$ merupakan remaja berusia 17 tahun. Sementara itu, terdapat satu atau sebesar $10 \%$ pelaku yang merupakan remaja berusia 13 tahun. Pelaku kasus cyberbullying yang tercatat di Kota Yogyakarta paling banyak dilakukan oleh remaja berusia 16 tahun. Hal ini sesuai dengan berbagai teori yang menyatakan bahwa potensi kenakalan remaja (juvenile delinquency) paling banyak pada usia 16-17 tahun. Menurut sudut padang psikologi sebagaimana yang dijelaskan oleh Elizabeth B. Hurlock, usia 16-17 tahun disebut sebagai "krisis remaja".12 Pada usia ini remaja akan mengalami gejolak pencarian jati diri. Pada fase tersebut seorang remaja rentan melakukan kenakalan berupa pelanggaran norma-norma hukum, sosial, susila, dan agama.

Suatu bentuk kenakalan remaja tertentu terkadang dipengaruhi oleh jenjang pendidikan seseorang. Maka dari itu penulis mencoba memaparkan pelaku cyberbullying berdasarkan jenjang pendidikannya. Hasilnya sebagaimana tabel di bawah ini:

Tabel 3 Tingkat Pendidikan Pelaku Cyberbullying di Kota Yogyakarta

\begin{tabular}{cccc}
\hline No & Pendidikan & Frekuensi (Orang) & Presentasi \\
\hline 1. & Sekolah Menengah Pertama (SMP) & 3 & $30 \%$ \\
2. & SMA/SMK/ Sederajat & 7 & $70 \%$ \\
\hline & Jumlah & 10 & $100 \%$ \\
\hline
\end{tabular}

Sumber: Data Primer, diperoleh dari Polda DIY, Polresta Kota Yogyakarta, dan Yayasan Lembaga Perlindungan Anak DIY

\footnotetext{
${ }^{11}$ Lidwina Esti Wulandari, Ps. Panit 1 Subdit IV Direskrimum Polda DIY

12 Hurlock, E.B. dalam Sudarsono. (2015). Kenakalan Remaja: Prevensi, Rehabilitasi, dan Resosialisasi. Jakarta: Rineka Cipta, h. 14.
} 
Sesuai dengan data yang tercatat oleh institusi di kota Yogyakarta, pelaku cyberbullying berdasarkan tingkat pendidikannya, di ketahui bahwa pelaku cyberbullying di Kota Yogyakarta seluruhnya adalah pelajar. Di mana rinciannya sebanyak tujuh orang atau $70 \%$ adalah pelajar pada tingkat SMA/SMK/Sederajat. Sementara itu sisanya sebanyak dua orang atau 30\% adalah pelajar Sekolah Menengah Pertama (SMP). Dari data tersebut terlihat jelas bahwa pelaku cyberbullying adalah remajaremaja terdidik. Pelaku cyberbullying didominasi oleh pelajar, sebab korban dari perbuatan tersebut umumnya adalah teman satu sekolah yang memang sudah sering berinteraksi baik di dunia nyata maupun melalui jaringan internet.

Berbagai teori mengenai kenakalan remaja mengaitkan tipe kenakalan tertentu dengan jenis kelamin. Maka sesuai dengan hasil penelitian, penulis akan memaparkan pelaku cyberbullying yang tercatat pada berbagai institusi di Kota Yogyakarta berdasarkan jenis kelamin sebagai berikut:

Tabel 4 Pelaku Cyberbullying yang Berdasarkan Jenis Kelamin

\begin{tabular}{cccc}
\hline No & Pelaku & Frekuensi (Orang) & Presentasi \\
\hline 1. & Laki-laki & 10 & $100 \%$ \\
2. & Perempuan & - & - \\
\hline & Jumlah & 10 & $100 \%$ \\
\hline
\end{tabular}

Sumber : Data Primer, diperoleh dari Polda DIY, Polresta Kota Yogyakarta, dan Yayasan Lembaga Perlindungan Anak DIY.

Sesuai dengan data yang tercatat oleh institusi di kota Yogyakarta, pelaku cyberbullying berdasarkan jenis kelamin, $100 \%$ pelakunya adalah laki-laki. Ini berbeda dengan penelitian yang dilakukan oleh banyak peneliti dari luar negeri, yang menunjukan bahwa perempuan lebih dominan melakukan cyberbullying karena sifat tidak langsung dari kejahatan tersebut. Sementara itu, laki-laki lebih cenderung melakukan kenakalan dengan menggunakan kekuatan fisik..$^{13}$ Penelitian yang dilakukan oleh Sameer Hinduja dan Justin W. Patchin dari Cyberbullying Research Center pada tahun 2009 di Amerika Serikat, mengungkapkan bahwa cyberbullying didominasi oleh perempuan. ${ }^{14}$

Perbedaan mencolok dari penelitian yang dilakukan di Amerika Serikat dengan fakta yang ditemukan oleh penulis di Kota Yogyakarta, dilandasi oleh berbagai faktor. Sebagaimana yang dijelaskan oleh Nur Fauzan, ${ }^{15}$ ada beberapa faktor yang menyebabkan pelaku cyberbullying di Kota Yogyakarta didominasi oleh laki-laki, yaitu:

1. Pelaku cyberbullying menggunakan akun yang dikenali;

2. Pelaku dan korban cyberbullying sudah saling kenal;

3. Cyberbullying merupakan pemicu tindak pidana kekerasan fisik;

4. Cyberbullying dan bullying secara tradisional dilakukan secara bersama-sama.

Berdasarkan faktor-faktor di atas wajar kiranya apabila pelaku cyberbullying di Kota Yogyakarta didominasi oleh laki-laki. Sebab meskipun cyberbullying dilakukan dengan tidak bertatap muka secara langsung, namun kedua belah pihak sudah saling mengenal, sehingga pelaku sudah mempertimbangkan bahwa dia adalah pihak yang dominan secara kekuatan fisik. Selain itu, pelaku cyberbullying telah mempersiapkan diri jika ada potensi terjadi kontak fisik. Fakta ini berbeda dengan cyberbullying yang banyak dilakukan oleh remaja di Amerika Serikat, di mana pelaku cenderung secara sengaja dan terencana melakukan cyberbullying untuk menganggu korban dengan menggunakan akun anonim (tidak dikenali). Pelaku menggunakan akun yang tidak dikenali sebab, dia tidak ingin atau tidak memiliki keberanian untuk melakukan kontak fisik, sehingga wajar jika cyberbullying di Amerika Serikat justru didominasi oleh perempuan.

\footnotetext{
${ }^{13}$ Marcum, C.D \& Higgins, G.E. (2009), Examining the Effectiveness of Academic Scholarship on the Fight Against Cyberbullying and Cyberstalking. American Journal of Criminal Justice, 11(2), h. 647

${ }^{14}$ Hinduja, S. \& Patchin, J.W. (2008), Cyberbullying: An Exploratory Analysis of Factors Related to Offending And Victimization. Deviant Behavior Journal, 11(3), h. 131.

${ }^{15}$ Nur Fauzan, selaku Ps. Kasubnit IV Reskrim Polresta Yogyakarta
} 
Korban kejahatan merupakan objek penelitian kriminologi yang tidak dapat dilepaskan dari gejala kejahatan. Dapat dipastikan bahwa setiap kejahatan ada korbannya, baik orang lain maupun diri sendiri. Banyak orang beranggapan bahwa korban kejahatan hanya sekedar pelengkap penderita bagi timbulnya suatu peristiwa kejahatan. Padahal pemikiran tersebut keliru, sebab korban sejatinya memiliki peranan yang besar bagi timbulnya suatu kejahatan. Oleh karena pentingnya peranan korban dalam memahami suatu kejahatan. Tabel dibawah ini menggambarkan jumlah korban cyberbullying yang tercatat pada berbagai institusi di Kota Yogyakarta, antara lain sebagai berikut:

Tabel 5 Korban Cyberbullying di Kota Yogyakarta

\begin{tabular}{clcc}
\hline No & \multicolumn{1}{c}{ Korban } & Frekuensi (Orang) & Presentasi \\
\hline 1. & Remaja Laki-laki & 2 & $33,3 \%$ \\
& $(12-17$ tahun) & & $33,3 \%$ \\
2. & $\begin{array}{l}\text { Remaja Perempuan } \\
\text { (12-17 tahun) }\end{array}$ & 2 & $33,3 \%$ \\
\hline & Institusi & 2 & $100 \%$ \\
\hline
\end{tabular}

Sumber: Data Primer, diperoleh dari Polda DIY, Polresta Kota Yogyakarta, dan Yayasan Lembaga Perlindungan Anak DIY.

Data di atas menggambarkan bahwa korban dari cyberbullying di Kota Yogyakarta dengan jumlah yang sama yaitu laki-laki dan perempuan. Hal ini terjadi karena perilaku cyberbullying di Kota Yogyakarta kebanyakan terjadi dalam ruang lingkup sekolah. Sebagian besar pelaku maupun korban merupakan teman sebaya yang telah saling mengenal satu sama lain. Hal tersebut yang menjadi alasan sangat jarang cyberbullying yang dilakukan oleh remaja ditujukan kepada anak-anak dan orang dewasa. Selain itu, berbeda dengan pelaku yang seluruhnya adalah remaja laki-laki, pada pihak korban terdapat remaja perempuan. Selain person (manusia), korban cyberbullying lainnya adalah institusi. Dalam hal ini institusi yang diserang adalah Kepolisian. Pranawa selaku Koorninator Layanan Hukum Yayasan Lembaga Perlindungan Anak DIY mengungkapkan bahwa kasus cyberbullying, di mana Institusi Kepolisian yang menjadi korbannya, terjadi karena adanya interaksi di dunia nyata antara pelaku dengan salah seorang yang bekerja di institusi tersebut. Namun si pelaku tidak berdaya dan tidak memiliki kekuatan untuk berhadapan dengan polisi tersebut, maka pelaku melampiaskannya melalui aksi cyberbullying.

Agar dapat dikatakan suatu perbuatan sebagai aksi cyberbullying, maka perbuatan tersebut harus dilakukan melalui media dalam jaringan internet. Adapun sesuai dengan penelitian yang penulis lakukan dari kasus cyberbullying yang tercatat pada institusi di Kota Yogyakarta, media yang digunakan oleh pelaku cyberbullying antara lain sebagai berikut:

Tabel 6. Media yang Digunakan Pelaku Untuk melakukan Cyberbullying

\begin{tabular}{clcc}
\hline No & Media & Frekuensi & Presentasi \\
\hline 1. & WhatsApp & 4 & $40 \%$ \\
2. & Facebook & 3 & $30 \%$ \\
3. & Instagram & 3 & $30 \%$ \\
\hline & Jumlah & 10 & $100 \%$
\end{tabular}

Sumber: Data primer, diperoleh dari Polda DIY, Polresta Kota Yogyakarta, dan Yayasan Lembaga Perlindungan Anak DIY.

Media yang paling sering digunakan untuk melancarkan aksi cyberbullying, sebagaimana data di atas adalah WhatsApps dengan total empat kasus atau dengan persentase 40\%. Empat kasus cyberbullying tersebut dilakukan pada chat rooms grup WhatsApps. Selanjutnya terdapat tiga kasus atau dengan persentase $30 \%$ menggunakan Instagram sebagai media untuk melakukan aksi cyberbullying. Kemudian terdapat tiga kasus atau dengan persentase sebesar 30\% cyberbullying yang menggunakan media sosial facebook. Sebenarnya frekuensi penggunaan media untuk melakukan cyberbullying bergantung pada tren pemakaian media sosial. Kasus cyberbullying yang dilakukan dengan menggunakan media facebook sempat terjadi pada tahun 2017, di mana media sosial facebook pada masa itu masih cukup populer. Sementara itu kasus cyberbullying yang menggunakan media sosial WhatsApp dan 
Instagram didominasi oleh kasus yang terjadi di tahun 2019, di mana pada tahun 2019 penggunaan dua media tersebut adalah yang paling masif di Indonesia.

Penulis juga melakukan penelitian ke Sekolah Menengah Atas (SMA) 7 Kota Yogyakarta, untuk menyebar 50 kuesioner yang ditujukan kepada siswa-siswi berusia 15 tahun sampai dengan 17 tahun. Terdapat 13 pertanyaan yang harus dijawab oleh responden dengan format sebagai berikut: S: Setuju, SS: Sangat Setuju, TS: Tidak Setuju, STS: Sangat tidak setuju. Di mana disetiap pertanyaan responden diwajibkan untuk memilih salah satu (multiple choice questions). Adapun hasil kuesioner tersebut sebagaimana tabel di bawah ini:

Tabel 7 Data Kuesioner Responden

\begin{tabular}{|c|c|c|c|c|c|}
\hline No & Daftar Pertanyaan & $\mathbf{S}$ & SS & TS & STS \\
\hline 1. & $\begin{array}{l}\text { Saya sangat sering menggunakan media sosial } \\
\text { (WhatsApp, Instagram, Twitter, dll) }\end{array}$ & 24 & 24 & 2 & 0 \\
\hline 2. & Saya sering melakukan cyberbullying & 11 & 0 & 26 & 13 \\
\hline 3. & Saya sering menjadi korban cyberbullying & 9 & 0 & 21 & 20 \\
\hline 4. & $\begin{array}{l}\text { cyberbullying merupakan perilaku yang } \\
\text { dikecam oleh masyarakat }\end{array}$ & 21 & 29 & 0 & 0 \\
\hline 5. & $\begin{array}{l}\text { Pelaku cyberbullying melancarkan aksinya } \\
\text { dengan menggunakan akun yang dikenali }\end{array}$ & 17 & 4 & 22 & 7 \\
\hline 6. & $\begin{array}{l}\text { Seseorang melakukan cyberbullying karena } \\
\text { perkembangan teknologi yang semakin pesat }\end{array}$ & 29 & 21 & 0 & 0 \\
\hline 7. & $\begin{array}{l}\text { Seseorang melakukan cyberbullying karena } \\
\text { meniru orang lain di media social }\end{array}$ & 19 & 31 & 0 & 0 \\
\hline 8. & $\begin{array}{l}\text { Seseorang melakukan cyberbullying karena } \\
\text { Ikut-ikutan teman }\end{array}$ & 24 & 20 & 6 & 0 \\
\hline 9. & $\begin{array}{l}\text { Seseorang melakukan cyberbullying karena } \\
\text { melihat tanyangan kekerasan dan cibiran di } \\
\text { televisi }\end{array}$ & 31 & 10 & 9 & 0 \\
\hline $\begin{array}{c}10 \\
.\end{array}$ & $\begin{array}{l}\text { Seseorang melakukan cyberbullying karena } \\
\text { kurangnya kelekatan dengan keluarga }\end{array}$ & 24 & 11 & 15 & 0 \\
\hline 11 & $\begin{array}{l}\text { Seseorang melakukan cyberbullying karena } \\
\text { Ingin mencari perhatian }\end{array}$ & 33 & 8 & 8 & 1 \\
\hline $\begin{array}{l}12 \\
\cdot\end{array}$ & $\begin{array}{l}\text { Seseorang melakukan cyberbullying karena } \\
\text { tidak tahu bahwa perbuatan tersebut } \\
\text { melanggar hokum }\end{array}$ & 27 & 5 & 16 & 2 \\
\hline $\begin{array}{l}13 \\
.\end{array}$ & $\begin{array}{l}\text { Upaya yang dilakukan oleh aparat penegak } \\
\text { hukum dalam memberantas cyberbullying } \\
\text { sudah efektif }\end{array}$ & 5 & 5 & 38 & 2 \\
\hline & JUMLAH & 274 & 168 & 163 & 45 \\
\hline
\end{tabular}

Sumber: Data primer, Hasil data Kuesioner dari responden pelajar berusia 15 tahun sampai dengan 17 tahun di SMA 7 Yogyakarta.

Berdasarkan tabel 7 sebagaimana di atas, dapat diketahui bahwa dari 50 responden yang mengisi kuesioner terdapat masing-masing 24 orang yang menyatakan setuju dan sangat setuju bahwa mereka sangat sering menggunakan media sosial (WhatsApp, Instagram, Twitter, dll). sementara hanya terdapat 2 responden yang menyatakan tidak setuju. Selanjutnya terdapat 11 responden yang setuju bahwa mereka sering melakukan cyberbullying. Sementara itu, terdapat 26 responden yang menyatakan tidak setuju dan 13 responden menyatakan sangat tidak setuju. Pertanyaan selanjutnya adalah berkaitan dengan seberapa sering mereka menjadi korban cyberbullying. Sebanyak 9 responden setuju bahwa mereka sering menjadi korban cyberbullying. Sementara itu, sebanyak 21 responden menyatakan tidak setuju dan 21 responsen menyebutkan sangat tidak setuju. Pertanyaan berikutnya yaitu cyberbullying sebagai perilaku yang dikecam oleh masyarakat. Di mana sebanyak 21 responden menyatakan setuju dan 29 lainnya menyatakan sangat setuju. 
Pertanyaan yang diajukan selanjutnya adalah identitas pelaku saat melakukan cyberbullying. Sebanyak 17 responden menyetujui bahwa identitas pelaku dikenali. Sementara itu terdapat sebanyak 4 responden sangat setuju, 22 responden tidak setuju dan 7 responden menyatakan sangat tidak setuju. Pertanyaan selanjutnya berkaitan dengan faktor-faktor yang menyebabkan seseorang melakukan perbuatan cyberbullying. Di mana secara umum responden menyetujui bahwa faktor-faktor yang menyebabkan seseorang melakukan cyberbullying adalah: pesatnya perkembangan teknologi, sifat anak yang suka meniru, ketidaklekatan hubungan dengan keluarga, serta ketidaktahuan dengan risiko hukum. Selain itu penulis juga memberikan pertanyaan terkait dengan efektifitas penegakan hukum terhadap pelaku cyberbullying. Mayorits responden tidak setuju, yang artinya responden menganggap bahwa penegakan hukum terhadap pelaku cyberbullying oleh penegak hukum tidak teraplikasikan secara efektif.

\section{B. Faktor-Faktor Penyebab Cyberbullying yang Dilakukan Oleh Remaja di Kota Yogyakarta}

Mempelajari serta menemukan faktor-faktor yang menyebabkan seseorang melakukan kejahatan memiliki perananan yang penting guna menentukan kebijakan kriminal (criminal policy) yang tepat dalam rangka menanggulangi kejahatan. Maka dari itu penulis akan memaparkan faktor-faktor yang menyebabkan remaja melakukan cyberbullying di Kota Yogyakarta. Setelah penulis melakukan penelitian, ditemukan faktor-faktor yang menyebabkan remaja melakukan cyberbullying di Kota Yogyakarta antara lain sebagai berikut:

1. Pesatnya perkembangan teknologi

Pesatnya laju modernisasi telah membawa perubahan secara signifikan dalam hal teknologi. Dampak dari perubahan teknologi informasi dan komunikasi pada akhirnya turut mengubah pola kehidupan dan lingkungan belajar serta bermain remaja di Kota Yogyakarta. Hadirnya jaringan internet, termasuk di dalamnya adalah media sosial, games online, situs web pribadi, ruang obrolan, email, dan pesan teks atau gambar digital, telah menjadi sarana yang mampu membuat banyak orang berinteraksi dalam dunia maya. Ketika terdapat interaksi dari banyak manusia, maka konflik tidak dapat dihindari.

Berbagai masalah akan timbul sebagai konsekuensi langsung dari cepatnya perkembangan teknologi. Jaringan internet dewasa ini telah menjadi fasilitas bagi aksi cyberbullying di Kota Yogyakarta. Banyak remaja di Kota Yogyakarta telah mengalami pergeseran pola bermain, yang dulunya dilakukan dengan berinteraksi di luar rumah, kini sedikit demi sedikit digantikan oleh interaksi di dunia maya, seperti media sosial dan games online. Penggunaan jaringan internet dengan intensitas yang tinggi ini yang membuat seorang remaja rentan melakukan cyberbullying. Salah satu contohnya, Sebagaimana yang dijelaskan oleh Wine Safitri, ${ }^{16}$ pada kasus anak dengan inisial MB yang merupakan pelaku cyberbullying, ternyata diketahui sudah tiga tahun sering pergi ke warnet untuk bermain game online sebelum akhirnya, ia melakukan aksi cyberbullying. MB biasanya bermain di warnet hingga larut malam, bahkan terkadang ia tidak pulang ke rumah dan tidur di warnet.

Sebanyak empat dari empat responden pelaku bullying tradisional dan cyberbullying yang sedang mendapatkan rehabilitasi di Balai Perlindungan dan Rehabilitasi Sosial Remaja Yogyakarta menjelaskan bahwa mereka kecanduan berselancar di dunia maya, terutama bermain games online dan media sosial. Berdasarkan berbagai contoh di atas, dapat diketahui bahwa semakin tinggi intensitas interaksi seseorang di dunia maya, maka semakin besar peluang ia melakukan cyberbullying.

Cyberbullying memiliki perbedaan dengan bullying yang dilakukan secara tradisional. Apabila bullying tradisional mensyaratkan pelaku dan korban berinteraksi secara langsung, namun tidak demikian dengan aksi cyberbullying. Sifat tidak langsung dari cyberbullying ini yang menjadi alasan maraknya aksi cyberbullying di Kota Yogyakarta. Sebab pelaku tidak terlihat secara langsung, serta dapat berlindung dibalik ponsel atau komputer.

Hal ini diperkuat dengan pengakuan dua responden remaja di Balai Perlindungan dan Rehabilitasi Sosial Remaja Yogyakarta. Mereka menyatakan bahwa motivasinya melakukan

16 Wine Safitri selaku Kasubsi Bimbingan Kemasyarakatan Anak, berdasarkan hasil penelitian kemasyarakatan 
bullying tradisional dan cyberbullying itu berbeda. Ia melakukan bullying tradisional karena memang pihak korban adalah pihak yang lebih lemah baik secara kedudukan maupun fisiknya. Sehingga ia dapat melakukan bullying berupa intimidasi dan kekerasan tanpa takut mendapatkan balasan. Sementara itu, motivasinya melakukan cyberbullying adalah karena ia dapat mengintimidasi dan mempermalukan korban dengan dampak yang sama tanpa harus menimbang-nimbang kekuatan fisik karena sifat tidak langsung dari cyberbullying.

2. Ketidaktahuan akan risiko hukum

Setelah penulis melakukan penelitian di berbagai tempat, ditemukan faktor berikutnya yang menyebabkan remaja melakukan cyberbullying di Kota Yogyakarta. Pranawa selaku Koordinator Devisi Layanan Hukum Yayasan Lembaga Perlindungan Anak DIY, Nur Fauzan selaku Ps. Kasubnid IV Direskrim Polresta Yogyakarta, dan Lidwina Esti Wulandari selaku Ps. Panit 1 Subdit IV Direskrimum Polda DIY, semuanya sepakat bahwa ketidaktahuan akan risiko hukum yang menyebabkan maraknya cyberbullying di Kota Yogyakarta. Pelaku cyberbullying kebanyakan tidak mengetahui bahwa perbuatan yang mereka lakukan adalah pelanggaran hukum. Mereka tidak mengetahui bahwa dari perbuatan tersebut, mereka dapat dikenai sanksi pidana. Para pelaku cyberbullying tersebut menganggap bahwa apa yang mereka lakukan hanya sebatas ungkapan ekspresi diri, atau bahkan beberapa di antaranya berdalih bahwa yang mereka lakukan hanyalah gurauan semata.

Berdasarkan keterangan Lidwina Esti Wulandari, ${ }^{17}$ menyebutkan bahwa remaja berinisial SR dan SCE yang merupakan pelaku cyberbullying, mereka tidak mengerti, tidak mengetahui, dan tidak menyangka bahwa hanya karena menggolok-olok temannya di grup WhatsApp ternyata dapat berbuntut panjang hingga harus diselesaikan di kepolisian. Kemudian Pranawa, ${ }^{18}$ menyatakan bahwa lima dari enam pelaku kasus cyberbullying yang didampingi oleh Yayasan Lembaga Perlindungan Anak DIY ternyata tidak memahami bahwa perbuatan mereka memiliki risiko hukumnya. Hal ini disebabkan karena undang-undang informasi dan transaksi elektronik itu baru dan belum banyak masyarakat yang memahaminya.

Ketidaktahuan akan risiko hukum juga dapat dilihat dari remaja pelaku cyberbullying yang umumnya menggunakan akun yang dikenali. Ini berbeda dengan cyberbullying yang dilakukan oleh orang dewasa, di mana sebanyak enam dari sembilan kasus cyberbullying yang dilakukan oleh orang dewasa yang ditangani oleh Reserse Kriminal Khusus Polda DIY pada tahun 2019 menggunakan akun yang tidak dikenali (anonymity). Sebab mereka paham betul bahwa dengan menggunakan akun anonymity, mereka akan lebih terlindungi, karena hal tersebut akan menyulitkan pihak kepolisian dalam mengungkap aksi cyberbullying. Sementara remaja dengan berani menunjukkan identitasnya saat melakukan aksi cyberbullying disebabkan sifat remaja yang terlalu polos dan tidak menyadari bahwa dengan menggunakan akun yang dikenali akan memudahkan pihak kepolisian untuk melacak keberadaannya.

3. Perilaku remaja yang suka meniru

Remaja merupakan masa transisi dari anak-anak menuju dewasa. Pada masa ini remaja memiliki kecenderungan labil, tengah mencari jati diri, dan antusias dalam mengeksplorasi banyak hal. Pada tahap ini remaja memiliki kecenderungan untuk melihat dan mempelajari berbagai hal dari lingkungan sekitarnya. Pembelajaran remaja selalu diidentikkan dengan berbagai interaksi antar kelompok yang memiliki kelekatan hubungan dengan dirinya, seperti keluarga, saudara, dan teman sebaya. Sebagai contoh adalah kasus cyberbullying yang dilakukan oleh remaja berinisial JTAF yang mengolok-olok institusi kepolisian, kemudian tingkah laku tersebut ditiru dan didukung oleh teman dekatnya berinisial DNC, dan DPA.

Di era modern ini, remaja tidak hanya dapat mempelajari tingkah laku dengan orangorang terdekat saja. Hadirnya media sosial menciptakan interaksi yang lekat tanpa harus saling kenal satu sama lain. Masalahnya banyak perilaku negatif yang dilakukan oleh banyak orang di media sosial yang pada akhirnya ditiru oleh remaja. Ini yang dialami oleh remaja berinisial SR dan SCE, mereka secara berulang-ulang melakukan cyberbullying dengan menyebarkan foto

\footnotetext{
${ }^{17}$ Lidwina Esti Wulandari selaku Ps. Panit 1 Subdit IV Direskrimum Polda DIY

${ }^{18}$ Pranawa selaku Koordinator Devisi Layanan Hukum Yayasan Lembaga Perlindungan Anak DIY
} 
korban yang telah diedit sedemikian rupa yang berbau pelecehan. Sebagaimana keterangan yang disampaikan oleh Lidwina Esti Wulandari, ${ }^{19}$ bahwa kedua remaja yang melakukan cyberbullying tersebut mengaku mempelajari tingkah lagu cyberbullying dari orang lain di media sosial. Mereka melihat tren penggunaan "meme" di media sosial dan kemudian diikutinya.

Perilaku remaja yang suka meniru juga dapat dilihat dari bullying secara tradisional yang dilakukan oleh beberapa remaja yang sedang mendapatkan rehabilitasi di Balai Perlindungan dan Rehabilitasi Sosial Remaja Yogyakarta. Awal mulanya terdapat satu remaja senior yang melakukan intimidasi dan kekerasan fisik kepada remaja junior. Kemudian tindakan bullying tersebut ditiru dan dilakukan oleh dua remaja lainnya. Ketika diwawancarai oleh penulis, dua responden tersebut mengungkapkan bahwa sebenarnya sebelumnya mereka tidak pernah melakukan bullying. Pembelajaran melakukan bullying terjadi di Balai Perlindungan dan Rehabilitasi Sosial Remaja Yogyakarta, di mana perilaku tersebut dilakukan dengan meniru remaja yang lebih senior ketika melakukan bullying.

Aksi cyberbullying terjadi karena perilaku remaja yang suka meniru tingkah laku disekitarnya ini sesuai dengan diferential association theory dari Edwin H. Sutherland yang menjelaskan bahwa "criminal behavior is learned in interaction with other person in process of communication".20 (tingkah laku kriminal dipelajari dalam interaksi dengan orang lain dalam suatu komunikasi). Seseorang anak tidak begitu saja menjadi delinquent hanya karena hidup dalam suatu lingkungan kriminal, namun sifat delinquent tersebut dipelajari dengan partisipasi bersama orang lain baik dalam komunikasi secara verbal maupun non-verbal.

4. Melemahnya kontrol sosial

Setelah penulis melakukan penelitian di berbagai tempat di Yogyakarta, ditemukan fakta bahwa cyberbullying yang terjadi di Kota Yogyakarta dapat dilakukan oleh siapapun. Meskipun ditemukan kecenderungan pada ciri tertentu, namun secara umum kejahatan ini tidak memandang faktor ekonomi, maupun faktor pendidikan. Pelaku cyberbullying dapat dilakukan oleh remaja dengan tingkat ekonomi rendah ataupun remaja yang lahir dari keluarga yang berkecukupan. Ditemukan pelaku cyberbullying yang merupakan remaja gemar bolos sekolah, namun juga terdapat remaja yang memiliki riwayat akademik yang baik.

Faktor yang menyebabkan seseorang melakukan cyberbullying selanjutnya terjadi karena melemah atau bahkan hilangnya kontrol sosial. Kontrol sosial dalam hal ini terbagi menjadi personal kontrol dan sosial kontrol. Pertama, kontrol internal atau personal kontrol yaitu kemampuan seseorang untuk menahan diri agar tidak mencapai kebutuhannya dengan melanggar norma-norma yang ada di masyarakat. Sebagai contoh, seorang remaja berinisial MB melakukan cyberbullying didasarkan karena rasa kesal terhadap korban. Sifat temperamen yang tinggi dan ketidakmampuan untuk menahan diri ini lah yang memicu pelaku melakukan cyberbullying. Berdasarkan hasil penelitian Balai Pemasyarakatan Kelas I Yogyakarta, ditemukan fakta bahwa melemahnya personal kontrol dari MB disebabkan oleh semakin menjauhnya MB dari nilai-nilai agama.

Melemahnya personal control juga terjadi pada kasus yang dialami oleh empat responden remaja di Balai Perlindungan dan Rehabilitasi Sosial Remaja Yogyakarta, Mereka mengaku mendapatkan kepuasan diri dalam melakukan bullying tradisional dan cyberbullying. Meskipun mereka mengetahui bahwa perbuatannya adalah sesuatu yang tidak baik dan dapat merugikan orang lain, namun mereka tetap melakukan cyberbullying karena ketidakmampuan mereka untuk menahan diri.

Melemahnya kontrol sosial juga dapat melibatkan faktor eksternal atau social kontrol, yaitu kemampuan kelompok sosial atau lembaga-lembaga di masyarakat melaksanakan normanorma atau peraturan-peraturan menjadi efektif. Cyberbullying terjadi karena melemahnya kontrol sosial dari keluarga, teman, dan masyarakat. Nilai-nilai dan etika dalam bertutur kata dan bertindak lambat laun semakin memudar yang disebabkan oleh laju modernisasi. Menurut pandangan penulis, lembaga kontrol sosial tidak lagi mampu untuk membimbing masyarakatnya, dalam hal ini remaja untuk memiliki etika dalam berinteraksi dengan orang lain. Selain itu

\footnotetext{
${ }^{19}$ Lidwina Esti Wulandari selaku Ps. Panit 1 Subdit IV Direskrimum Polda DIY

20 Sutherland, E.H. dalam Hadisuprapto, P. (2006). Juvenile Delinquency: Pemahaman dan Penangunangannya. Bandung : PT. Citra Aditya Bakti, h. 20.
} 
banyak kasus baik bullying tradisional maupun cyberbullying terjadi karena melemahnya peran norma agama dan norma sosial dalam diri si remaja. Dalam hal ini masyarakat dan keluarga tidak mampu membimbing remaja tersebut. Sebagai contoh pada kasus remaja berinisial MB, di mana orang tua pelaku membiarkan pelaku bermain game di warnet hingga tengah malam, bahkan terkadang tidak pulang ke rumah.

Melemahnya social kontrol juga dapat terlihat dari kasus yang dialami oleh empat responden remaja di Balai Perlindungan dan Rehabilitasi Sosial Remaja Yogyakarta, Mereka mengaku telah jauh dari nilai-nilai agama. Selain itu mereka juga mengaku selama ini tidak mendapatkan pengawasan yang baik dari orang tua maupun lingkungan sekitar tempat tinggalnya.

\section{Simpulan}

Berdasarkan hasil penelitian yang dilakukan ada beberapa faktor penyebab remaja melakukan cyberbullying di Kota Yogyakarta antara lain:

1. Pesatnya perkembangan teknologi yang membawa perubahan pola bermain bagi remaja. Penggunaan jaringan internet dengan intensitas yang tinggi yang membuat seorang remaja rentan melakukan cyberbullying. Selain itu, sifat tidak langsung dari cyberbullying juga memengaruhi seseorang melakukan cyberbullying;

2. Ketidaktahuan akan risiko hukum yang menyebabkan kebanyakan pelaku cyberbullying tidak mengetahui bahwa perbuatan yang mereka lakukan adalah pelanggaran hukum. Mereka tidak mengetahui bahwa dari perbuatan tersebut mereka dapat dikenai sanksi pidana;

3. Perilaku remaja yang suka meniru yang dipengaruhi oleh masa transisi dari anak-anak menuju dewasa. Pada tahap ini remaja memiliki kecenderungan untuk melihat dan mempelajari berbagai hal dari lingkungan sekitarnya. Pembelajaran tersebut dilakukan dengan kelompok-kelompok yang memiliki kelekatan hubungan dengan dirinya, seperti keluarga, saudara, dan teman sebaya;

4. Melemahnya kontrol sosial yang dapat dibedakan menjadi personal control yaitu kemampuan seseorang untuk menahan diri agar tidak mencapai kebutuhannya dengan melanggar normanorma yang ada di masyarakat dan social control, yaitu kemampuan kelompok sosial atau lembaga-lembaga di masyarakat melaksanakan norma-norma atau peraturan-peraturan menjadi efektif.

\section{Daftar Pustaka.}

\section{Buku}

Fajar ND, M \& Achmad, Y. (2017). Dualisme Penulisan Hukum Normatif \& Empiris. Yogyakarta: Pustaka Pelajar

Hadisuprapto, P. (2006). Juvenile Delinquency: Pemahaman dan Penangunangannya. Bandung : PT. Citra Aditya Bakti

Mardina. R. (2019). Kekerasan Terhadap Anak dan Remaja. Jakarta: Infodatin

Maskun. (2014). Kejahatan Siber (Cyber Crime): Suatu Pengantar. Jakarta: Prenada Media Group.

Ravena, D \& Kristian, (2017), Kebijakan Kriminal (Criminal Policy). Jakarta: Kencana

Sudarsono. (2015). Kenakalan Remaja: Prevensi, Rehabilitasi, dan Resosialisasi. Jakarta: Rineka Cipta

\section{Jurnal}

Donegan, R. (2012), Bullying and Cyberbullying: History, Statistics, Law, Prevention and Analysis, The Elon Journal of Undergraduate Research in Communications, 1(3).

Marcum, C.D \& Higgins, G.E. (2009), Examining the Effectiveness of Academic Scholarship on the Fight 
Against Cyberbullying and Cyberstalking. American Journal of Criminal Justice, 11(2), h. 647

Hinduja, S. \& Patchin, J.W. (2008), Cyberbullying: An Exploratory Analysis of Factors Related to Offending And Victimization. Deviant Behavior Journal, 11(3), h. 131.

\section{Makalah}

Asosiasi Penyelenggara Jasa Internet Indonesia (APJII). (2009). Laporan Survei Penetrasi \& Profil Prilaku Pengguna Internet Indonesia.. Jakarta: 10 April 2019.

\section{Regulasi}

Undang-Undang Nomor 11 Tahun 2008 Tentang Informasi dan Transaksi Elektronik jo Undang-Undang Nomor 19 Tahun 2016 Tentang Perubahan Atas Undang-Undang Nomor 11 Tahun 2008 Tentang Informasi dan Transaksi Elektronik.

Undang-Undang Nomor 11 Tahun 2012 Tentang Sistem Peradilan Pidana.

\section{Website}

Tim Penyusun Wikipedia. (2019). Daftar Negara Menurut Jumlah Pengguna Internet. Diakses pada tanggal $17 \quad$ Oktober 2019, pukul 20.08 WIB, https://id.wikipedia.org/wiki/Daftar negara menurut jumlah pengguna Internet 